\title{
Opalski syndrome
}

\section{Ipsilateral hemiplegia due to a lateral-medullary infarction}
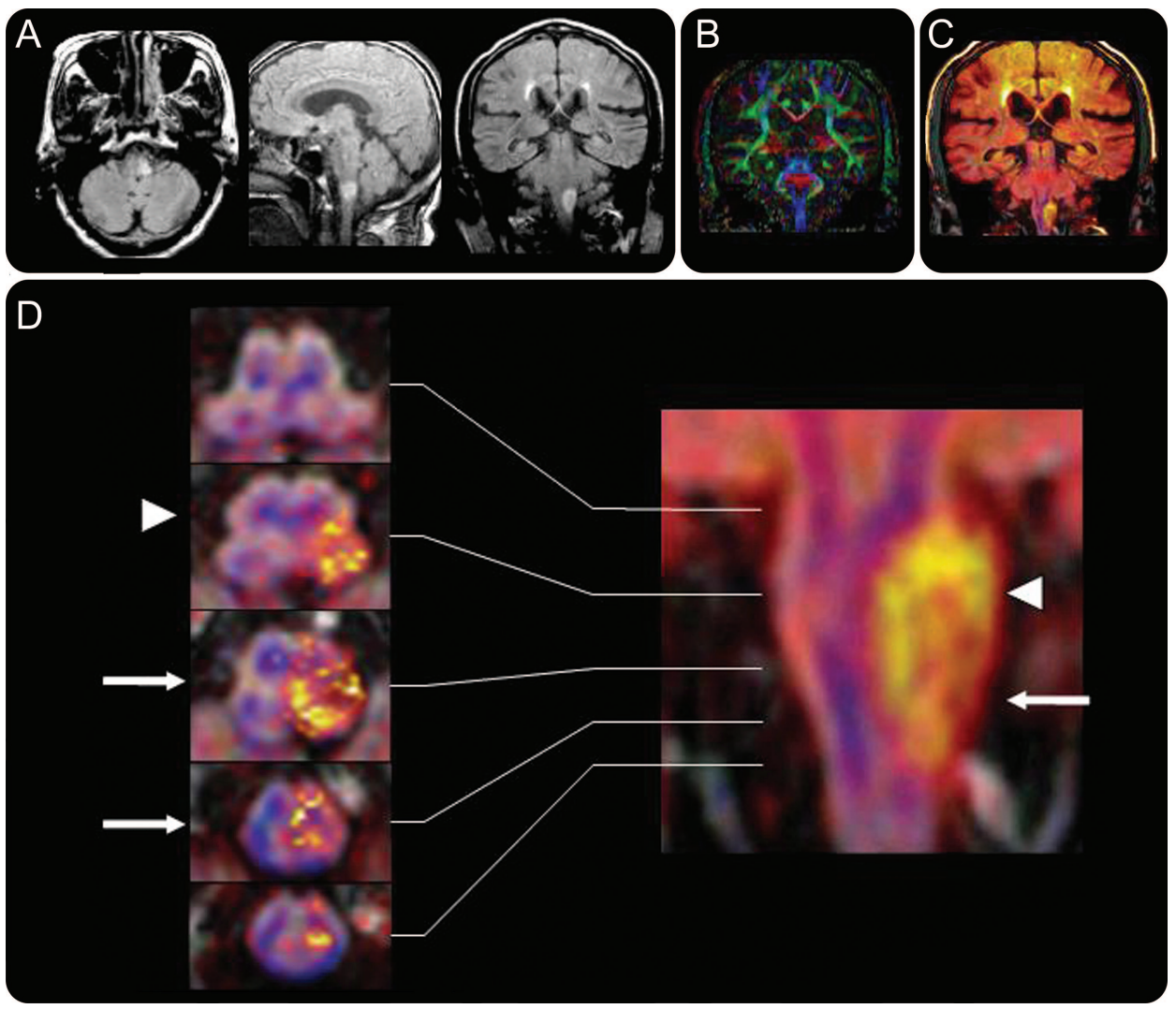

Fluid-attenuated inversion recovery MRI (A). Directionally encoded map with hues reflecting tensor orientation (B). Superimposed images (C, D): a yellow halo represents the infarct and blue lines represent the pyramidal tracts (coronal); the tracts fuse at the decussation (transverse). Caudal extension of the lesion involves the ipsilateral corticospinal tract (arrows) after the decussation (arrowheads).

A 66-year-old man developed left hemiparesis, left Horner sign, and sensory loss on his left face and right limbs, without contralateral hemiparesis or tongue weakness. MRI demonstrated a left lateral-medullary infarction (figure, A). A rare variant of lateral-medullary syndrome, Opalski syndrome, ${ }^{1}$ manifests as ipsilateral hemiplegia; however, the anatomic basis is not established. ${ }^{2}$ Therefore, we generated a directionally encoded color map (figure, B) using diffusion tensor imaging techniques and superimposed the images (figure, $\mathrm{C}$ and $\mathrm{D}$ ). These suggest that involvement of the ipsilateral corticospinal tract after the pyramidal decussation, or compression of the decussation, could cause Opalski syndrome.

Shinichiro Nakamura, MD, Makiko Kitami, MD, Yoshiaki Furukawa, MD, Tokyo, Japan

The authors thank Takashi Tabuchi of the Medical Satellite Yaesu Clinic for technical assistance.

Disclosure: The authors report no disclosures.

Address correspondence and reprint requests to Dr. Shinichiro Nakamura, Department of Neurology, Juntendo Tokyo Koto Geriatric Medical Center, 3-3-20, Shinsuna, Koto, Tokyo 136-0075, Japan; nakamura@juntendo.gmc.ac.jp

1. Montaner J, Alvarez-Sabín J. Opalski’s syndrome. J Neurol Neurosurg Psychiatry 1999;67:688-689.

2. Hermann DM, Jung HH, Bassetti CL. Lateral medullary infarct with alternating and dissociated sensorimotor deficits: Opalski's syndrome revisited. Eur J Neurol 2009;16:e72-e74. 


\section{Neurology}

\section{Opalski syndrome: Ipsilateral hemiplegia due to a lateral-medullary infarction}

Shinichiro Nakamura, Makiko Kitami and Yoshiaki Furukawa

Neurology 2010;75;1658

DOI 10.1212/WNL.0b013e3181fb4479

\section{This information is current as of November 1,2010}

\section{Updated Information \&} Services

References

Subspecialty Collections

Permissions \& Licensing

Reprints including high resolution figures, can be found at: http://n.neurology.org/content/75/18/1658.full

This article cites 2 articles, 1 of which you can access for free at: http://n.neurology.org/content/75/18/1658.full\#ref-list-1

This article, along with others on similar topics, appears in the following collection(s):

Clinical neurology examination

http://n.neurology.org/cgi/collection/clinical_neurology_examination Infarction

http://n.neurology.org/cgi/collection/infarction

MRI

http://n.neurology.org/cgi/collection/mri

Information about reproducing this article in parts (figures,tables) or in its entirety can be found online at:

http://www.neurology.org/about/about_the_journal\#permissions

Information about ordering reprints can be found online:

http://n.neurology.org/subscribers/advertise

Neurology ${ }^{\circledR}$ is the official journal of the American Academy of Neurology. Published continuously since 1951, it is now a weekly with 48 issues per year. Copyright Copyright @ 2010 by AAN Enterprises, Inc.. All rights reserved. Print ISSN: 0028-3878. Online ISSN: 1526-632X.

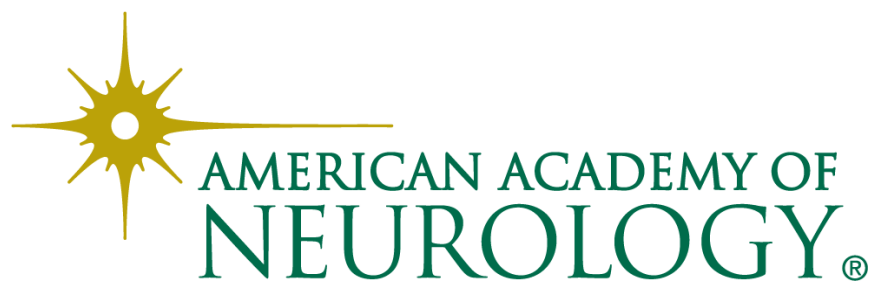

